\title{
THE THISTLE BIRD
}

\author{
By W. WARD SIMPSON \\ (From "The Cardinal," London, Ont.)
}

Gaily he swings on the thistle, lightly he swings through the air. Here he comes to take his accustomed song-perch on the highest twig of this little elm. The nest is in the apple tree close by.

Sweet and low he sings, then more loudly and more rapidly. There is happiness, there is form and rhythm in the song, but as the speed increases, gradually all form and rhythm disappear. Only mad joy remains. No longer is the song a fast-flowing stream of sweet notes. It has become a bubbling fountain and a spray. The notes crowd one another. They come tumbling out with incredible rapidity, spilling over in all directions. He has sung himself into a frenzy; the spirit holds him in its power. Never a moment has he paused to rest, and long after we had begun to marvel at such amazing expenditure of energy, the song went on and on.

There is however, a limit to his strength. The spirit releases him calmness returns. A moment's silence, then, lightly he springs into the air; in rhythmic undulations, he circles the small adjacent field. Now it is his flight song we hear, "perchicoreeperchicoree," one musical phrase to each undulation of his flight.

The Goldfinch is of the essence of joy. Only the Ruby-crowned Kinglet is his rival as the exponent of the spirit of eternal gladness. It is well that the finch nests over almost the whole of the continent. All may know him and enjoy his golden presence. I have long ceased to correct those who would call him the Wild Canary. They outnumber us. The matter of a name is not important with a bird so eminently equipped to win his way into every human heart.

Emerson said, "The worth of a bird is not in his ounces or inches, but in his relation to Nature." He doubtless had in mind the economic aspect. Here the Goldfinch rates very high indeed. Secds of weeds, thistles, and burs are his main diet, though he also co-operates importantly in

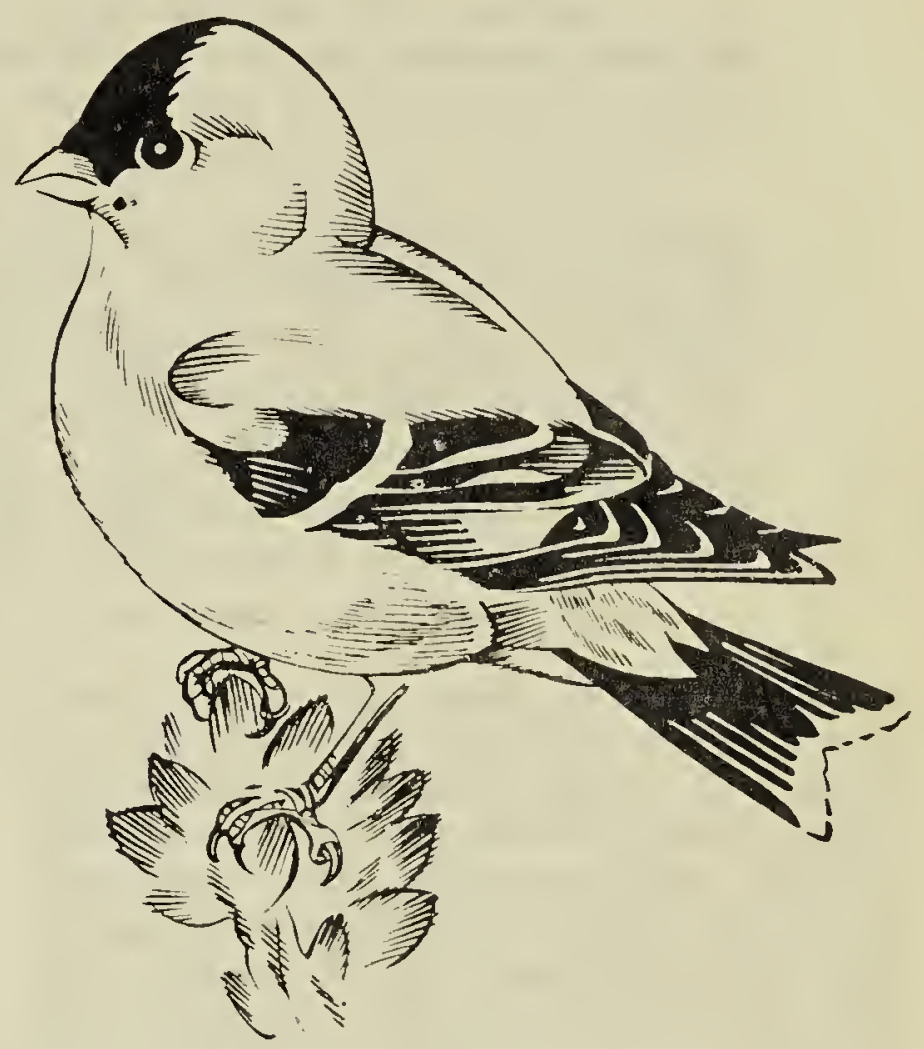

the work of his insectivorous friends.

Here is an example of his exploits. A flock of sixty, wintering in a woodland in which were many pine trees, found an abundant food supply in a great patch of pitchfork burs nearby. A careful calculation forced us to the conclusion that there were more than two million individual bur seeds over that acre of ground.

During that winter these birds opened every bur with a clever twist of their bills, extracted and ate the seeds, and dropped the empty husks upon the snow. What a boon to the falmer who likes a clean farm and clean livestock, is the work of these eatcrs of weed seeds!

Birds have character and personality. There lies close to the south bank of the great Dundas Valley a wildly beautiful natural park. Along the farther bank of a small stream, a wooded hill rises steeply. A great pine tree grows from the water's edge. Attempting to pass between the tree and the steep bank we grasp a bough. A female Goldfinch flies out and perches on the tip of a small tree twenty feet away. She is immediately joined by her mate. They face us, uttering, not scolding notes, but sweet beseeching cries, "swercet.

(Continued on Pagr 31) 